\title{
Funny Bone finds a home: A musical featuring the Body of Christ
}

\begin{abstract}
Author:
Robin Gallaher Branch ${ }^{1,2}$

\section{Affiliations:}

${ }^{1}$ Faculty of Theology, North-

West University, South Africa

${ }^{2}$ Department of Bible and

Theology, Victory University,
\end{abstract}

Memphis, United States

\section{Correspondence to:}

Robin Gallaher Branch

Email:

rgbranch@victory.edu

\section{Postal Address:}

255 North Highland,

Memphis, Tennessee

38111, United States

\section{Dates:}

Received: 24 July 2012

Accepted: 25 June 2013

Published: 20 Nov. 2013

How to cite this article: Branch, R.G., 2013, 'Funny Bone finds a home: A musical featuring the Body of Christ', In die Skriflig/In Luce Verbi 47(1), Art. \#113, 17 pages. http://dx.doi.org/10.4102/ ids.v47i1.113

\section{Note:}

The play is dedicated to the Reverend Evelyn Lupardus who is a funny bone in the Body of Christ.

\section{Copyright:}

(C) 2013. The Authors. Licensee: AOSIS OpenJournals. This work is licensed under the Creative Commons Attribution License.

Read online:

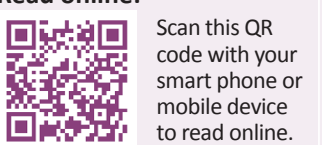

This play is a teaching tool and examines the concepts of unity and disunity in the Body of Christ. Based on 1 Corinthians 12:12-27, the play contains as characters the body parts mentioned by Paul in his instruction on the need for honouring different ministries and functions in the church. Combining humour and song, the play follows in the steps of ancient medieval allegories and illustrates a biblical teaching in a contemporary way.

Funny Bone: 'n Musikale blyspel wat die Liggaam van Christus uitbeeld. Hierdie musiekblyspel kan vir onderrigdoeleindes gebruik word. Dit ondersoek die eenheids- en konflikaspekte in verband met die Liggaam van Christus. Dit is gebaseer op 1 Korintiërs 12:12-27 en die karakters van die toneelstuk beeld die verskillende liggaamsdele uit soos deur Paulus genoem in sy opdrag om die verskillende evangeliebedienings en funksies van die kerk te erken. Deur humor en sang te kombineer, volg die toneelstuk die voetspore van 'n antieke Middeleeuse sinnebeelding en illustreer bybelse onderrig op ' $n$ hedendaagse wyse.

\section{Introduction}

1 Corinthians 12:12-27, a text about the Body of Christ, teaches biblical principles through humour. An appropriate response is laughter. Actually, humour may well be a fundamental theme in both testaments. ${ }^{2}$ By making characters of the body parts, this play takes Paul literally and carries on his use of imagination. Funny Bone herself is an imaginary character and takes her name from the recognised body part located at the end of the elbow.

This play approaches 1 Corinthians with a light touch, ${ }^{3}$ for after all, the letter is addressed to a congregation Paul loves. ${ }^{4}$ The musical employs imagination, ${ }^{5}$ a God-given gift, for the text (whether read or heard) invites readers and hearers to engage it and to participate in it. ${ }^{6}$

I come to the biblical text from the reformed tradition. My heritage is the Presbyterian Church, a denomination that combines trained, learned preaching from the clergy and active congregational involvement. ${ }^{7}$ Preaching in the presbyterian tradition emphasises both order in worship and liberty within worship. ${ }^{8}$ It acknowledges the ability and need of the congregation to participate in the service. ${ }^{9}$ My training is that of a biblical scholar for a classroom rather than as a preacher for a pulpit ministry. I serve the academy and church by teaching. I write and publish plays, because I find my students learn by doing and memorising. As a biblical scholar, I seek to present thoroughly researched plays based on sections of Scripture in thoroughly engaging ways. ${ }^{10}$ This is my fifth such

1. Funny Bone is a Christian drama containing humour and music. 1 Corinthians 12:12-27 contains humour because of its incongruities (see Arbuckle 2008:2). Edyvean (1970:18-19) writes that Christian drama presents ideas like human responsibility, Christ's centrality, confession, forgiveness, fellowship and hope.

2.See Arbuckle 2008:19. Iverson (2011) believes that, whilst we laugh at Jesus' disciples who forgot to take bread on the boat even though they had witnessed a miraculous feeding of four thousand (Mk 8:1-21) and clearly the joke is on them, 'we end up laughing at ourselves as well'.

3.Theology contains sacred experiences that are 'accessible to the contemporary heart and mind' (Wells 2004:35-36). I agree with McNabb and Mabry (1990:22) who state that a Bible teacher's job is to present the text in an understandable way. Funny Bone follows Loader's (2007:ix) lead in pausing to reflect on the 1 Corinthians 12 text with imagination whilst remaining within its parameters.

4.As a writer of a musical based on the biblical text, I see God's dramatic involvements throughout Scripture (cf. Pitzele 1998:221-224; Branch 2010a:181-184)

5.Brueggemann (2005b:21) argues that preaching can provide an 'alternative imagination'; Funny Bone certainly does that.

6.Loader (2007:ix) invites readers to see the New Testament in 'a new way: through imagination'. He guides imagination with facts about New Testament times, social customs, farming practices, taxation, unemployment, et cetera.

7.John Chrysostom outlined principles for preaching, including being straightforward, biblical and down to earth (see Stott 1982:20-21). Funny Bone employs allegory and is a straightforward teaching tool.

8.The book of common worship (1946:vi) notes that 'the Presbyterian Church has always emphasised its liberty and has left its ministers free as to the form and order of worship'. A suggestion is to have the passage taught in a traditional sermon during the morning worship and then explained in Funny Bone that evening. A minister could open the service by reading 1 Corinthians 12:12-27 and thereby introduce the play.

9.The book of common worship (1946:vi) notes that people in congregations want a more active participation in Christian worship, 'which was the custom in the Early Church and is the heritage of the Protestant Reformation'.

10.In this, I follow Stott (1982:180) who notes that there is a freshness and vitality about every sermon borne of study. 
play; four others have been published by academic journals (Branch 2004:4(1), 57-69; 2010b:44(1), 229-258; 2013a:47(1); 2013b:47(1). I like and employ Brueggemann's (2005a:51) insight that a musical like Funny Bone can serve as a teaching tool to 'summon and nurture an alternative community with alternative identity, vision, and vocation, preoccupied with praise and obedience toward the God we Christians know fully in Jesus of Nazareth' (italics Brueggemann's). The church at Corinth is an alternative community.

This musical uses the standard elements of a play. ${ }^{11}$ It also employs a literary methodology and a canonical perspective in examining 1 Corinthians. ${ }^{12}$ Funny Bone differs from a drama or tragedy in the sense that, as a comedy, it intends that reversals, errors and our all-too-human 'booboos' produce, not calamity, but prosperity and happiness. ${ }^{13}$ I wrote Funny Bone with a smile to show our common human foibles with kindness. I also wrote it with a sense of adventure, because studies indicate that people today do not trust the old church modes. ${ }^{14}$

The Christian classic The Humor of Christ (Trueblood 1964) strongly influences my teaching, thinking, Bible reading and playwriting. Trueblood (ibid:15) believes that we fail to see not only the wit and humour of Jesus, but also his expectation that we should laugh. I see Paul's writings like this passage from 1 Corinthians in this vein. We are intended to laugh at the absurdity of nonchalantly not needing a hand (1 Cor 12:21). Arguably, Jesus and Paul could not have influenced people without being enjoyable to be around. Humour as well as sound teaching draws people together. With this in mind, I encourage my students to laugh at a literal interpretation of a big old camel squeezing itself through an itsy-bitsy needle (Mt 19:24), the absurdity of a homeowner putting a lamp under a bed (Mk 4:21), ${ }^{15}$ and the bumbling suitor who means well when he likens his sweetheart's hair to a flock of goats (Can 6:5). Similarly, Paul's skilful analogy of body parts combines good teaching with humour; it makes me laugh. My musical puts Paul's teaching on stage. ${ }^{16}$ Whilst writing this play, I took seriously Trueblood's (ibid:32) observation that 'any alleged Christianity which fails to express itself in gaiety, at some point, is clearly spurious'. Throughout this play's research, writing and productions, I prayed that it would serve as a teaching tool for the academy and church

11.A play's standard elements include plot, character, dialogue, setting, staging and theme. The musical acknowledges symbolism, irony and repetition as well as teaching and writing tools (DiYanni 2008:920-935).

12.Hill and Walton (2000:575) note that a literary analysis focuses on character development and features like the use of motifs, vocabulary, syntax and literary elements. It excludes avenues like historical and archaeological background. I view the text in its final canonical form, its composite whole, and consider it Scripture (Hill \& Walton ibid:575)

13.See DiYanni (2008:918)

14.See Brueggemann (2005b:17).

15.Arbuckle (2008:33-34) provides a helpful list of humour as a teaching method Jesus employed, which includes this and other insights, like a parent giving his child a stone instead of bread (Mt 7:9)

16.I agree with Stott's (1982:9) belief that good preaching is essential to the healthy growth of a healthy church, and I add that good teaching is essential too. Stott (ibid:138) mentions a difficulty preachers face: the rift between the biblical and modern world. I wrote Funny Bone as a way of putting Paul's teaching, which I hold to be inspired, in a contemporary setting. As a teacher, I know that songs help my to be inspired, in a contemporary setting. As a teacher, I know that songs help my
students memorise. So I included songs as another teaching tool. A good sermon students memorise. So I included songs
has variety; so does a good musical. to strengthen all concerned in their union with Christ and to engage them in ministry. ${ }^{17}$

\section{Setting the stage Characters}

Head, Foot, Ear, Nose, Unpresentable Parts, Hand, Eye, Heart, Piano Player, and Funny Bone.

With the exception of the last three, these are recognised members $^{18}$ of the Body of Christ, as mentioned in 1 Corinthians 12:12-27. ${ }^{19}$ Heart is mentioned in 1 Corinthians 14:5. The funny bone is a body part located on the end of the elbow and is associated with mirth and laughter. ${ }^{20}$ Foot and Head are probably played by men and Unpresentable Parts and Heart by women. ${ }^{21}$ Eye may bring oversized eyeglass and Hand may wave a gigantic mitt.

\section{Costumes}

The characters wear T-shirts with their names across the front, or they dress in a contemporary fashion. If the latter, Head probably wears a business suit or a fashionable golf outfit. Foot is in sandals. Unpresentable Parts is in layered tank tops, leggings and a short skirt. Funny Bone can be a bit outlandish with a wild tie, khakis, suspenders and a hat if played by a man, or a fun, long skirt, big belt, sandals and bright top with long sleeves if played by a woman. If T-shirts are chosen, individuality comes from the undershirts, caps, shoes or sandals, skirts, pants and wigs the characters may then include.22 Eye may bring oversized eyeglass and Hand may wave a gigantic mitt.

\section{Set}

The setting is a nice but fairly bare room. ${ }^{23}$ The stage has an assortment of comfortable chairs. A bar table with bar stools is downstage right in front of a piano. A sofa with pillows is upstage, centre stage. Houseplants decorate throughout. A rug is centre stage - this is where the huddles take place. A box of tissues is on an end table. The setting could well be the front altar area of a church, for an altar area usually

17.In this, I follow the presbyterian resource book, The service for the Lord's Day (1984:7). Additionally, Funny Bone concentrates on two of Osmer's (2008:4) guidelines regarding practical theological interpretation: it incorporates theatre art and presents a particular situation in Corinth in a contemporary way.

18.'Our bodies have members', writes Dever (2011:94). Membership is basic to human communities. The character Funny Bone served her apprenticeship as a volunteer with the established members of the Body of Christ.

19.All Scripture verses are from the New International Version, with the exception of Proverbs 17:22 which is the King James Version. In this 1 Corinthians passage Paul 'takes in the totality of the individual members, refers to the body, and demonstrates its basic unity', Kistemaker (2002:429) writes. Smalley (1968:431) adds that 1 Corinthians 12 covers spiritual gifts 'not in isolation but in relation to the church as the body of Christ'.

20.See The Random House dictionary of the English language (Urdang \& Urdang 1973:575). A funny bone is located at the end of an elbow. A funny bone is also associated with a good sense of humour.

21. Funny Bone, with its cast of allegorical characters, continues a tradition of Christian drama that includes the Dorothy Sayers' radio play The man born to be king (Brown 2008:174).

22.An actor recreates the author's character with gestures, tone, pauses and costumes (see Von Balthasar 1988:284). In Funny Bone, each character at times stars, leads and commands centre stage.

23.A minimal stage allows the writer to verbalise a scene (see Pitzele 1998:39). Nine people and a piano crowd the stage; furniture should be of good quality, sturdy and in levels, like a bar table and two high chairs. 
contains levels that permit effective staging. ${ }^{24}$ The characters enter through an aisle in the audience. ${ }^{25}$

\section{Atmosphere}

There's general good will and busy talk amongst the members of the Body of Christ as they enter. ${ }^{26}$ They ad lib at will. ${ }^{27}$ Heart carries a nicely wrapped package which she puts on an end table on stage. Funny Bone nods and smiles, but doesn't take part in the banter. ${ }^{28}$ Everybody smiles frequently..$^{29}$ Until reprimanded, Nose does pick his nose!

\section{Opening scene}

Unpresentable Parts: How are you, Foot? ${ }^{30}$

Foot:

Great! I'm glad to see you again, Unpresentable Parts. ${ }^{31}$

Hand:

Give me five, Foot! [They slap hands.] $]^{32}$

Ear:

I've heard good reports about you, Nose. ${ }^{33}$

Nose:

Thanks, Ear! It's so good to see everybody again. ${ }^{34} \mathrm{I}^{\prime} \mathrm{m}$ looking forward to hear what's been happening to my friends in the Body of Christ.

Head:

Right! We haven't had a meeting for a long, long time!

Eye:

We need to get together! I've missed seeing each of you ${ }^{35}$

Heart:

Eye, what have you been doing? What's the Lord doing through you?

24.1 agree with Long (2001:44) who views a worship service as a play performed in a kind of community theatre, with God as the audience and the worshipers as actors.

25.Long (2001:43-44) acknowledges the controversies surrounding dramas' role in worship. Worship is not a spectacle (Long ibid:44), but inherently a participatory event with willing and joyful assemblers. Good teaching, like good preaching, seeks to honour and engage the audience, and combine ideals and reality (see Stott 1982:10, 29).

26.Von Balthasar (1988:343) writes that 'dramatic action is possible and meaningful only within a given situation' and setting. Funny Bone follows Brueggemann's (2005b:19) view that the audience 'interprets the text in the here and now of the members' lives; the text does not operate in a vacuum'.

27.The play permits ad libbing. Through improvisation, actors may put themselves into the story (see Anderson 2006:15)

28. Funny Bone follows this idea presented by Bolte and McCusker (1993:5-6): A play provides a snapshot on an issue and is a good teaching tool for youths and adults.

29.Smiles increase one's 'face value' (see Swindoll 1991:17). I agree with McNabb and Mabry (1990:21) who see the Bible not only as a positive book, but also as containing lots of fun.

30.Paul affirms that congregation members are equal, wanted and needed (see Kistemaker 2002:440).

31. Funny Bone may also be considered a bibliodrama. A bibliodrama begins with the ability to read the text creatively and to see that 'the text is given a voice and answers me back', Pitzele $(1998: 26,28)$ writes.

32. Drama concentrates on actions, but comedy directs attention to gestures (Bergson 1924:143).

33.McNabb and Mabry (1990:21) maintain that the Bible needs to be seen not as a tool that keeps people from having fun, but as a way of discovering in community 'the greatest news ever heard'.

34.The characters exhibit a pride that Paul sees as destructive (1 Cor 11-14; Loader 2007:80).

35.Paul shows that the Eye wants 'to be independent of the other parts of the body' (Kistemaker 2002:435).
Eye:

Hand:

Head:

[Proudly.] Well, I was used so greatly recently by the Lord. I want to tell everybody about it! ${ }^{36}$

So was I! The Lord worked miracles through me! I'm not called Hand for nothing! ${ }^{37}$

What you say reminds me of my own ministry experience, Hand and Eye. Oh, let me tell you about it! I knew just what to do! My study during a sabbatical certainly paid off! I was so very proud. ${ }^{38}$

Ear: Well, my recent congregations are measured in acres of people. I preached first in Korea and then in Africa. I had a translator at each service. People listened to me with rapt attention. I was very well received. ${ }^{39}$

Heart: $\quad$ I'm glad, Ear. My speaking engagement went so well that I have three more bookings!

Unpresentable Parts: My goodness, Heart, you must be earning a lot of money! ${ }^{40}$

Foot:

I've gone the farthest of all of you since our last meeting. I keep going to remote places. I brought the Gospel to a mountain valley at 10000 feet. I can't tell you the country, because it is officially closed to the Gospel. But I was faithful to give the Good News to all, including the poor. ${ }^{41}$

Nose: [Kindly, with understanding.] I'm sure you were, Foot. My fellow members of the Body of Christ, we can continue catching up after our meeting. ${ }^{42}$ We must greet Funny Bone! Funny Bone, it's good to see you again. I'm sure you're ready with a joke. ${ }^{43}$

Eye:

Yes! Greetings, Funny Bone! ${ }^{44}$ Let's hear a joke! Funny Bone, bless us with a joke! ${ }^{45}$

36.Loader (2007:70) invites readers to imagine Paul as he wrote the letter's drafts that included attacks on idolatry and hypocrisy, and also the self-righteous pride that Eye introduces here.

37. Hand presents not only a theatrical moment, but also a theological truth based on experience. Vanhoozer (2005:79-80) sees several benefits to 'knowing God theatrically', including reinvigorating 'our anemic imaginations' and seeing the ordinariness of daily life as a window for God's intervention.

38.Eslinger (2005:175) writes that most first-person stories in a sermon do not serve their intended purposes of demonstrating solidarity with the congregation or making a point immediately.

39. Head, Ear and Heart's evangelism stories indicate pride in themselves more so than oy in spreading the Gospel message. Bailey (2011:344-345) outlines several aspects of Paul's view of evangelism in 1 Corinthians 12:22-24: evangelism involves persona relationships, needs a long-term commitment and must be motivated by love.

40.If the Corinthian congregation contains those who are high-status society members, they may look down on members like Unpresentable Parts which they deem lowe class. Paul emphasises that these members, who may be an embarrassment, must be clothed and seen with dignity and honour (Hays 1997:215-216). A 1 Corinthian theme is the lack of charity toward the poor on the part of the rich (see Ramell 2011:145).

41.What Foot calls the Good News, Vanhoozer (2005:37-38) may call theology: what God has said and done, and the response of human beings to his ongoing actions.

42.Nose states another textual theme: the passage talks about the Body - not the church - of Christ, an unexpected wording (see Fisk 2000:79).

43.DiYanni (2008:923), writing on the essential nature of characters, states that characters bring a play to life.

44.Funny Bone, an attractive character, smiles, worries about nothing, prays about everything and relaxes (see Swindoll 1991:199-201).

45.Studies find that humour and 'the telling of stories and jokes occur with almost equal frequency and are human characteristics shared by both sexes', write Peter and Dana (1982:115). Funny Bone displays what Arbuckle (2008:2) calls 'laughter of the heart' - an interior peace and joy. 
Funny Bone:

[Laughing.] $]^{46}$ Well, after listening to all of you, your talk reminded me of something opposite - but humorous - I read recently. Here it is: 'The Low Self-Esteem group will meet as usual on Thursday at $7 \mathrm{pm}$. Because the church has a wedding that night, the wedding party requests that the Low Self-Esteem group use the back door'.

\section{[General laughter by the characters.]}

Head:

[Laughing.] ${ }^{48}$ Yes, the back door! Thank you, Funny Bone! Well, it's time for the meeting to come to order. Find your places, Body of Christ. As usual, I'll take charge.

Foot: Why is it always you? Why can't someone else preside? ${ }^{49}$

Head:

[A bit nasty.] Like you, for instance? $?^{50}$ You step all over people! Like Heart? A softie in community decisions?

[Head and Foot glare at Head. Heart looks sad, and Foot looks mad.]

Head:

No, no. I'm the best choice. I'm always chosen.

[The other members of the Body of Christ do not look pleased. They scatter around the stage. Funny Bone stands by a bar stool.]

Head:

[Very business-like.] Yes. Yes. Well, let's get going. I have a golf game to go to Evangelism on the golf course, you know. Yes. Yes. [Looking at Funny Bone.] Well, this meeting has been called because of you, Funny Bone. Funny Bone wrote to me asking for time to talk to all of us.

Hand:

Welcome to you, Funny Bone.

Ear:

We're glad you're here. You always make us laugh with your jokes.

Unpresentable Parts: Yes, she does! But they're always nice jokes! Do you have one right now? We seem to have some ruffled feathers and need a little diversion! ${ }^{51}$

46. Laughter makes a person human. Aristotle in Poetics defined man as a rationa animal capable of laughter' - suggesting that man is the only animal who does laugh (Welsh 1967:95).

47.Arbuckle $(2008: 8-9,23)$ says negative laughter includes irony which is saying one thing and meaning another, mockery and scoffing, and calls (ibid.9) caricature 'risky' and urges caution when using it. Satire criticises, sarcasm expresses ridicule, and parody impersonates with exageration (Arbuckle ibid:10-11). On the positive and parody impersonates with exaggeration (Arbuckle ibid:10-11). On the positive side, wit maks ibid:13, 16).

48.Von Balthasar (1988:436) writes that 'laughter is as much a part of life as weeping'.

49.Foot and the others resent Head for misusing his gifts of leadership and organisation, and for overlooking others' gifts. Wells (2004:36) comments that the underwritten patriarchal social experience of the winners, the men in charge, has 'inhibited women's freedom, experience, voices, ministries, lives'.

50.Conflict is expressed as rudeness and confrontation. Conflict, a significant literary tool drawn from the plot and the central idea, occurs when competin or opposing forces collide (Lostracco \& Wilkerson 2008:19). Reading canonically conflict appears throughout the New Testament. Consider Jesus' conflict with the chief priests and elders over authority (Mt 21:23-27), Saul's conflict with the therly church (Ac 9:1-2) and divisions in Corinth regarding whom to follow (1 Cor garding whom to follow (1 Cor

51.By covering an awkward social situation with laughter, Unpresentable Parts follows what Welsh (1967:97-99) considers its essential element: a relaxed rather than an intense attitude.
Funny Bone:

[Laughing. $]^{52}$ Sure! I came prepared! I know you! The Body of Christ has plenty of humour, because it's full of people $!^{53}$ This was in a church bulletin: 'Because of a conflict, the peace-making meeting scheduled for today has been cancelled.' [Laughter.]

And here's a cute story about selfconfidence. A student asked his teacher to raise his grade from an A to an A+. The teacher asked why. The little boy flashed a missing-tooth grin and said, 'Because that's how good I am!'54

[General laughter. $]^{55}$

Heart:

Thank you, Funny Bone. Laughter certainly clears the mind - and the air! $!^{56}$ Now tell us why you've called us together. ${ }^{57}$

Nose:

Yes! We're all curious!

Funny Bone:

Well, it's simple! I love each of you so much! When you ask me, I work with you on assignments from the Lord. I'm a member of the Body of Christ - but sort of on an informal basis. ${ }^{58}$ Well, I want to be more involved. I like being with you! I'd like to be formally recognised as a member of the Body of Christ ${ }^{59}$

[The members react with surprise and a stunned silence.]

Nose: $\quad$ My goodness! You! You in the Body of Christ! ${ }^{60}$ That never occurred to me! ${ }^{61}$

Ear: Amazing! Mygoodness! How unusual! ${ }^{2}$

Head: We'll have to check the Scriptures!

Funny Bone:

Yes! Of course! I want you to search the Scriptures. Let me state my case by singing about it. ${ }^{63}$

52.The audience will laugh frequently throughout the play. It is well-known that the fuller the theatre, the more the laughter (Bergson 1924:6-7).

53.Arbuckle (2008:iii, 40) argues that humour pervades the Bible because of God's pursuing and forgiving love of fickle humanity.

54.See Glavich (2002:106).

55.Multi-faceted laughter can be an act of reflection, occur spontaneously, comment on something in a tit-for-tat fashion, and/or punish recognisable human failings (Bergson 1924:197-198).

56.Laughter has many helpful by-products. Cousins (1979:86-87) used laughter to combat an illness and was 'convinced that creativity, the will to live, hope, faith and love have biochemical significance and contribute strongly to healing and to well-being'. Laughter and imagination form tools for training a congregation in the faith (see Stonehouse 1998:158).

57.Funny Bone's request forms the central idea of the drama. Lostracco and Wilkerson (2008:1) say that a story's central idea 'reveals the author's point of view on some aspect of life'.

58.Funny Bone stresses what Paul does: Christ, rather than the church. The passage's usual interpretation is that all Christians have gifts which they must contribute to and share with the church (see Wright 2004:158)

59.The characters' reaction is consistent with Scripture, for Paul's use of the human body and its comparison with Christ is a surprise. One expects Paul to compare the body and the church (Kistemaker 2002:429).

60.Anderson (2006:9-10) believes there are two ways to approach a study of the Bible: academically in a classroom, and as an 'attempt to stand within the Bible and to look out at the world through the window of biblical faith' (italics Anderson's). Funny Bone uses the latter.

61.Funny Bone's declaration represents a dramatic moment: a new, controversia thought is introduced. Long (2001:48) says that dramatic worship involves flow and pacing.

62.Echoing is a tool in bibliodrama (see Pitzele 1998:47).

63.Throughout Funny Bone, keep in mind what Wells (2004:61) calls a 'creative fidelity' to the text. 
Unpresentable Parts: Funny Bone, I'll tell you right now that I want you to be recognised! ${ }^{64}$

Funny Bone:

Thank you so much, Unpresentable Parts!

[Funny Bone bows and Unpresentable Parts curtsies.]

\section{Song: Sung by Funny Bone} Tune: 'Home on the range' ${ }^{6}$

Oh, give me a home in the Body of Christ

For I am Funny Bone

I'll make you laugh with my silly gaffes ${ }^{66}$

For chuckles add years to your life. ${ }^{67}$

I am Funny Bone

Stick with me and you'll be tickled!68

For smiles and mirth make you many friends

And get you out of a pickle! ${ }^{16}$

All:

[Clapping enthusiastically.] Thank you! Well sung! [Funny Bone laughs with them and bows. $]^{70}$

Head: $\quad$ You state your case well, Funny Bone. ${ }^{71}$ Now, let us introduce ourselves to you and tell you about our roles in the Body of Christ. ${ }^{72}$ The apostle Paul likened the church to a human body with various parts. ${ }^{73}$ Paul named each of us here in 1 Corinthians 12 and elsewhere. ${ }^{74}$ Our job descriptions are based on Scripture. After we tell you about ourselves, you can see if you really want to join us, and we'll discuss it if you really do fit in. ${ }^{75}$

Funny Bone:

Great! I'll listen with much interest. ${ }^{76}$

64.Dever (2011:98) defines formal membership as a commitment of Christians in the name of God to one another.

65.The tune to 'Home on the range' is in the public domain; see Robert McEwen, Esq (2009).

66.Berryman (1999:358) comments that laughter is a legitimate use of power in religious education. As a teacher, I find that my students learn more when smiling.

67.Funny Bone makes laughter a habit. The Orthodox Church believes Easter should be a day of laughter and hilarity, for it showcases God's triumph and sets it aside as such (Copenhaver 2007:15, 17).

68.Copenhaver (2007:17) correctly writes that comedy is closer to the deep springs of the Christian religion than is tragedy.

69.Funny Bone is intended to be sung and enjoyed (see Murfin \& Ray 1997:286).

70.Welsh (1967:102) finds 250 biblical references to laughter and varieties thereof in the biblical text.

71.Stevenson-Moessner (2008:20) writes that in the 21st century there is a wide acceptance of new and different culture voices, like, for example Funny Bone's.

72.Great theatre means that the actor experiences a kind of self-forgetting. The actor becomes so absorbed in what he or she says that the hows and whys of the performance recede (Childers 1998:96).

73.Theology can be studied as a range of sacred experiences 'accessible to the contemporary heart and mind' (Wells 2004:35-36). Funny Bone looks at Paul's theology and arguments in 1 Corinthians 12 with honour, honesty and humour. Church tradition includes such open discussion (see Ac 15).

74.In 1 Corinthians 12:21 Paul turns to personification. Those who view themselves as superior see themselves as being able to get along without others (see Fee 1987:612).

75.Jesus identifies himself completely with the church; see Acts 9:4 (Kistemaker 2002:429).

76.Using their imagination and knowledge of Jesus, Rice and Yaconelli (1987:7) posit that the Master may have used skits especially to illustrate parables.
[Funny Bone walks stage right. During the singing, Funny Bone walks naturally all over the stage. Gradually, Funny Bone's face becomes more and more concerned. Throughout the play she actively listens. $]^{77}$

Ear:

[Sarcastically.] Well, I guess Head starts! ${ }^{78}$

Head: Of course. I'm always the first in any line. Let me introduce myself.

[Head is quite formal and bows profusely. The other body parts mimic or guffaw. $]^{79}$

\section{Song: Sung by Head}

\section{Tune: Russian Hymn ('God the Omnipotent') ${ }^{\text {s0 }}$}

Greetings to all of you. I am the Head. ${ }^{81}$

I am not the tail.

I am always the first.

You look to me - as well you should -

For I plan ahead for the common good!

[Head bows. There is lukewarm applause. Head continues bowing.]

Head: [Misinterpreting the acclaim.] I'll sing it again! I'm more than ready! ${ }^{82}$

Eye: $\quad$ No, no! We get the message $!^{83}$

Unpresentable Parts: [Kindly.] We all know your work, Head. We appreciate you and thank you. ${ }^{84}$

Foot:

I'll go next. I'm more than ready. I'll tell you about myself. Head started. But I'm where the rubber meets the road! 85 There's an old saying that an army is only as good as its feet!

\section{Song: Sung by Foot}

\section{Tune: 'Onward, Christian Soldiers ${ }^{\prime 66}$}

One foot then the other

Following where He leads

Faithfully He guides us, meeting all our needs

Jumping, walking, running-

Do what 'ere He says

Forward, backward, sideways

Never be dismayed!

77.McNabb and Mabry (1990:177-180) outline a mentor's qualities as listening, not needing to be perfect, guiding and loving a person younger in faith or experience toward Christian maturity.

78.Bergson (1924:4) writes that comedy contains an absence of feeling, because laughter needs indifference; laughter's greatest foe is emotion.

79.Berryman (1999:364-368) presents four categories of laughter: superiority, incongruity, relief and a pleasant psychological shift. Head portrays the superior model, and the response is guffaws, muted laughter and grimaces.

80.The tune to 'God the Omnipotent' is in the public domain (Pilgrim Hymnal 1966:446, 554).

81.See Deuteronomy 28:13.

82. Head does not see his own arrogance. Bergson (1924:146-147) comments: 'Profoundly comic sayings are those artless ones in which some vice reveals itself in all its nakedness: how could it thus expose itself were it capable of seeing itself as it is?

83.The words and actions of the Body of Christ show the members' good and bad attitudes (see Lostracco \& Wilkerson 2008:28).

84.Laughter, joy and kindness are all attitudes of choice - ones a wise person selects (see Swindoll 1991:45).

85.Puns, an aspect of humour, can 'intensify the active experience of reading the text' (Pitzele 1998:11-12)

86.The tune to 'Onward, Christian soldiers' is in the public domain (Pilgrim Hymnal 1966:382, 553). 
One foot then the other

Trusting with each step

Marching behind Jesus,

Gracious Priest and King. ${ }^{87}$

All:

Well sung, Foot! We need you in the Body of Christ, Foot! Here! Here!

Nose: Just change your socks more often! [Agreement and laughter.]

Unpresentable Parts: And cut your toenails! ${ }^{88}$ Ugh!

Hand:

Hey, Foot! Didn't I see you going into a building that ... ${ }^{89}$

Foot: [Interrupting strongly.] No, you did not! Let's change the subject! ${ }^{90}$

Ear:

Come to think of it, I remember hearing something, too. Oh, tell us where you went! We want to know! !1 $^{1}$

Nose:

Come on Foot, fess up! We know you're prone to wander from time to time.

Foot:

[Folding his arms and walking away.] I go where I want! I'm not accountable to any of you! I don't have to tell you a thing! ${ }^{92}$ Humpf!

[General outrage and disagreement come rapidly after Foot's statements.]

Eye:

How arrogant!

Head:

Preposterous! ${ }^{93}$

Unpresentable Parts:

Heart:

Well, I never!

Nose:

Such pride! How could Foot say that!

What an attitude!

Head:

Heart:

Ear:

Order, order, everybody! Foot is right! He doesn't have to say where he's been, although we would like to know. But Foot needs to remember that our individual reputations as members of the Body of Christ reflect on us all. ${ }^{44}$

But it's more important that we remember that whatever we do reflects on our Lord and Saviour Jesus Christ. May we seek to honour him.

What do you say to that, Foot?

87.Foot ends strongly with an emphasis on Jesus as King (see Wright 2004:159).

88. Rough, earthy humour in drama can bring understanding smiles at our shared humanity. For examples of this from Scripture, see Brown (2008:161).

89.Steuernagel (2003:103) points out that theology begins with unexpected encounters often set in the messy confines of our day-to-day lives.

90. Head, Foot and Eye face uncomfortable truths about themselves, showing that theatre succeeds when a spectator is compelled 'to face the concrete dramatic dimensions of his own life', writes Von Balthasar (1988:265).

91.Words reveal the characters' motivations, attitudes, cover-ups, hopes, fears, loves and hates (see DiYanni 2008:901).

92.Foot is responsible for his behaviour and happiness (see Swindoll 1991:71).

93.Robinson's advice (2001:80-79) for good preaching applies to good teaching: present concepts clearly.

94. Here I show that Foot's behaviour addresses a theme in 1 Corinthians: some in the congregation 'have used their new sense of freedom to live in ways which seem to ignore moral values and the need to let faith affect the way' that they live (Loade 2007:81).
[Everybody looks to Foot. He shrugs his shoulders. There's an uneasy standoff between Foot and the other members Funny Bone, neutral and observant, ponders this.]

Hand:

[Breaking the uncomfortable silence.] I think I may have the solution. The Epistle of Jude says this: 'Let the Lord

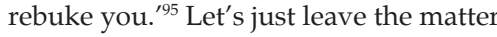
of where Foot may have gone to the Lord. Let's trust that the Lord - if necessary - will discuss the matter with Foot.

Ear:

Good idea, Hand.

Nose:

Yes, thank you, Hand. [Turning to Funny Bone.] Funny Bone, we need another joke! ${ }^{96}$

Funny Bone: [Rising to the occasion.] Well, let's change the subject. Here's a bit of humour about a first grader who was sent to the principal by her teacher, because she disturbed other children. The little girl explained her behaviour to the principal this way: 'I guess I have restlessness in my blood! $!^{\prime 97}$

[General laughter.]

Heart:

Thank you, Funny Bone. Your humour helps us, as usual. I'll go next. I'm brief and concise..$^{98}$

\section{Song: Sung by Heart Tune: 'Row, row, row your boat ${ }^{\text {'9 }}$}

Heart, Heart, Heart I am

Beating every day

My mercy, compassion, forgiveness and love $\mathrm{e}^{100}$

Come from God above.

Eye:

That was so good, Heart, that you need to repeat it.

Heart: Sure thing! Follow me!

[The members of the Body of Christ fall in line behind Heart in a march. Some skip. Some dance. They all sing.] $]^{101}$

\section{Song: Sung by All (repeated twice) Tune: 'Row, row, row your boat'}

Heart, Heart, Heart I am

Beating every day

95.See Jude 9 .

96.The play shows that the Body of Christ knows that Funny Bone chooses joy and cultivates a sense of humour (Swindoll 1991:77).

97.See Glavich 2002:96.

98.Eslinger (2005:176), writing on the efficacy of concrete images in good preaching, notes that they are helpful for a communal identity. Funny Bone's characters clearly portray both strengths and weaknesses and are therefore good teaching tools.

99.The tune to 'Row, row, row your boat' is in the public domain; see Public Domain Information Project (PD Info) (n.d.).

100.Biblically based theatre helps open people's 'hearts to the good news of the scandalous love of God for his people' (Cloninger 1999:11).

101. Heart, with a military step, leads a disorganised line through the audience. Bergson (1924:29) notes that 'attitudes, gestures and movements of the human Bergson (1924:29) notes that attitudes, gestures and movements of the human
body are laughable in exact proportion as that body reminds us of a mere body are laughable in exact
machine' (italics Bergson's). 
My mercy, compassion, forgiveness and love

Come from God above. ${ }^{102}$

[General laughter and good will from the members of the Body of Christ. $]^{103}$

Unpresentable Parts: Oh, Heart, everybody loves you. I wish I were like you! Everybody wants to follow you!

Heart:

[A bit smugly.] Yes, I know I'm loved.

Nose:

Thank you, Heart. Unpresentable Parts, you have to sing, too!

Unpresentable Parts: Well, all right! It's the highest form of courage to stand in front of a group! I'm overcoming my glossophobia!

Head:

[Informing everybody.] Glossophobia - if you don't already know - is the fear of speaking before a group. ${ }^{104}$

Unpresentable Parts: Thank you, Head.

\section{Song: Sung by Unpresentable Parts Tune: 'Tenting tonight on the old camp ground' 105}

I am well-known in the Body of Christ

As Unpresentable Parts

Sometimes I embarrass the gently bred

With my immodesty

But I don't know what to do, my friends,

With all my energy

I need help controlling my hormones

And must shun immorality!

UnpresentableParts! Unpresentable Parts!

I am my own problem

Lord, I cry to you! Show me how to serve

And bless your Holy Name!'

Ear:

[Thoughtfully, thinking aloud.] God has given us a great gift in our sexuality, but sometimes how we use our sexuality creates problems!

Foot:

[Kindly.] Thanks, Unpresentable Parts, for talking with us about your struggles. ${ }^{106}$ Thank you for letting us hear you bring your need to the Lord.

Heart: [She takes the wrapped present from the end table.] Unpresentable Parts, this seems like a good time to give you the present I bought for you. ${ }^{107}$

102. Robinson (2001:60) encourages reading teaching and preaching 1 Corinthian 12-14 in context. Love, as Heart indicates, is central to Paul's teaching (1 Cor 13).

103.Arends (2008:74) writes that laughter resembles a glue 'that attaches us to the goodness that inhabits this world and to the gladness that hints of the world to come'.

104. Head certainly shows no fear of public speaking. The Corinthians may have taken sides in judging who was the best public speaker amongst Peter, Paul and Apollos (Loader 2007:81).

105.The tune to 'Tenting tonight on the old camp ground' is in the public domain; see PD Info (n.d.).

106. Because Unpresentable Parts shares her struggles, shows emotion, extends gracious acceptance, displays anger and at times reflects on the words and actions of the other characters, she is what Lostracco and Wilkerson (2008:13) call a dynamic character.

107.Paul makes the point that both modesty and decency should be Christian characteristics (see Kistemaker 2002:437).
[She hands the box to Unpresentable Parts who is very pleased. ${ }^{108}$ She opens it and takes out a lovely shawl that just happens to be a match her outfit. She drapes it across her shoulders and the members of the Body of Christ smile and clap. $]^{109}$

Head:

[Taking charge again.] That was a very nice gesture, Heart. ${ }^{110}$ Thank you. Let's move on, everybody. Time is money! Money is time! Eye, you've been looking mighty smug through all this. What do you have to say for yourself?

Eye:

Plenty! I'm ready and sharp! My vision is clear. Call me 20/20!

\section{Song: Sung by Eye}

\section{Tune: 'Mine eyes have seen the glory' ${ }^{111}$}

[Eye begins slowly. As the song progresses, the tempo increases. Eye, quite dramatic, may march around the stage.]

I am the Eye and function in the Body of Christ

I spy, I peer, I look, I gaze to see the path ahead

And I alert you all so that you can be led

Away from the miry pit!112

I am more than essential

I am quinte- quintessential

I am more than essential

I am the Eye! Amen!

Hand:

My goodness, Eye. You call yourself more than essential! Probably some of us disagree! You sound full of pride to me! $!^{113}$

Foot: To me, too!

Eye: Humph! Well, I know my value. Try functioning without me and see how much I'm needed! [Eye pulls out a blindfold.] Here! Let me tie this on you! [Hand backs away.] Come here, Foot! You'll fall in a ditch without me! See how far you get in the mountains without me! [Foot also backs away from being blindfolded.]

Heart:

Careful, Eye. Your attitude sounds over the top! $!^{114}$

Eye: $\quad$ No, it is not! I know my value! I don't need you! ${ }^{115}$

108.Unpresentable Parts expresses unexpected joy at Heart's gift (see Arends 2008).

109.A mentor gives someone younger in the faith meaningful opportunities to express faith (McNabb \& Mabry 1990:180).

110.Via Unpresentable Parts, Paul encourages the congregation's privileged members 'to respect and value the contributions of those members who appear to be their inferiors' (Hays 1997:213).

111.The tune to 'Mine eyes have seen the glory' is in the public domain (Pilgrim Hymnal 1966:443, 554).

112.See Psalm 30:3; 40:2; 103:4.

113.Eye's attitude and song create conflict. Conflict 'results from a cause and effect relationship between events' (Lostracco \& Wilkerson 2008:19).

114.Eye's elitist behaviour illustrates Paul's point that diversity - not uniformity - is essential for a healthy church (Fee 1987:583).

115.Paul disdains Eye's and Head's independent attitudes (see Kistemaker 2002:435). Perhaps the great error Paul seeks to correct is an arrogant self-sufficiency and the demeaning way of thinking: 'I do not need you' (see Fee 1987:612-613). 
[A general bad feeling prevails against Eye as it did first against Head and then against Foot.]

Nose:

[Talking to everybody.] Hey, let's be civil. ${ }^{116}$ We're commanded to act with humility and to esteem others as better than ourselves. ${ }^{117}$ Jesus commanded us to love one another as he loves us. ${ }^{118}$ We're all acting puffed up. ${ }^{119}$ What do you think Jesus thinks of all this? ${ }^{120}$

[In general, the members of the Body of Christ want to continue fighting. They turn their backs on an extended hand from Nose. They shake their heads when he comes to them.]

Nose:

[Very discouraged.] All I can do is pray. ${ }^{121}$

\section{Song: Sung by Nose \\ Tune: 'Danny Boy'122}

Lord Jesus Christ, your body is not unified. ${ }^{123}$

We fight and hate and show you no respect.

We tear and wound each other with impunity.

There is no health amongst us anymore. ${ }^{124}$

Lord Jesus, come and turn our Heart again to you.

Oh, set our Feet along your narrow path

And may our Hands be lifted high in praise to you ${ }^{125}$

And may our Eyes behold your lovely, lovely face.

[Heart, Foot, Hand, and Eye all appear sad. Nose's song convicts them of $\sin .]^{126}$

Eye:

[Reflectively.] You're right, Nose. All I want to do is to see the lovely face of Jesus. I'm sorry for my arrogance, Body of Christ.

Foot:

[Admitting guilt.] Thank you, Nose, for your song. It gives me courage for what I must confess. ${ }^{127}$ Yes, I went into a bar.

116.The cycle of discontent that seems prevalent in the congregation at Corinth prevails today. After an initial welcome wears off, a member may express envy and jealousy, and carry grudges (see Kistemaker 2002:434).

117.See Philippians 2:3.

118.See John 15:12

119.See 1 Corinthians 4:18, 19; 8:1.

120.Peter and Dana (1982:113) write that 'adding a ridiculous element, such as an exaggeration, is often a way to express empathy with another', as when Nose extends his hand and receives rejection.

121.Bonhoeffer (1954:84-85) comments that we pray, guided by Scripture, asking for preservation from sin, growth in sanctification, and faithfulness in our work. Nose's prayer concentrates on sanctification.

122.The tune to 'Danny Boy' is in the public domain; see PD Info (n.d.).

123.Via his song, Nose leads the Body of Christ in worship, a dramatic corporate event (see Long 2001:43). Von Balthasar (1988:25) adds that drama illuminates Christian theology.

124.Freedom in Christ is also a 1 Corinthians theme. The Corinthians understood this (erroneously) to mean, as Allard (2010:400) writes, a freedom from all restraints. They thought they were free to eat meat dedicated to idols (1 Cor 8:1-13) and engage in sexual liaisons with prostitutes (1 Cor 6:15), that a man could have sexual relations with his father's wife (1 Cor $5: 1)$, that women could disrupt service (1 Cor 14:34) and that women need not wear veils (1 Cor 11:2-16; Allard ibid:400). Nose correctly sings: 'There is no health amongst us anymore.'

125. Nose clarifies Paul's message of freedom: believers are set free to serve their neighbours, for 'service is the motif of the gospel' (see Allard 2010:401-402).

126.Quash (2005:3-4) provides some valuable insights that apply to Funny Bone's tone: 'Drama displays human actions and temporal events in specific contexts. Theodramatics concerns itself with human actions (people), temporal events Theodramatics concerns itself with human actions (people), temporal events
(time), and their specific contexts (place) in relation to God's purpose' (italics Quash's).

127.See James 5:16; 1 John 1:19; Proverbs 28:13.
I had too many drinks and did not represent Jesus well because of things I said and did there. I said suggestive words to a woman and got into a fight. The police were called, but luckily I was not arrested. I am ashamed of myself. I did not honour Jesus. I know that my actions also reflect on you, for I am part of the Body of Christ. In addition, my attitude showed arrogance and pride. [Foot looks contrite and ashamed.]

Hand:

[Reflectively.] I think, Foot, I speak for all of us in forgiving you. [Hand looks around and members of the Body of Christ nod.] But Nose, your song, also spoke to me. ${ }^{128}$ The choice for me is always between doing things for myself or doing things for Jesus. You see, I can make things like a building or an airplane. I can write things like a book or a poem. I can hold a child or shoot a gun. I have such amazing power. But when I lift my hands in praise to Jesus, ${ }^{129}$ I surrender my pride. I am asking for his direction. I am praising him.

Heart: [Nodding.] Right, Hand. I must guard against deceiving myself. Scripture says this about me: 'The heart is deceitful above all things. ${ }^{\prime 130}$

[There's a general quiet for a moment or two. The characters are not so much sad as reflective. This meeting is becoming deeper than they thought! It certainly is raising issues. Funny Bone senses this and moves around the characters giving encouragements like a pat on the shoulder, high-fives and sideways hugs.]

Ear:

What you say, Nose, has cut me to the quick. I, too, have a confession to make to you, my fellow members in the Body of Christ. ${ }^{131}$

Head:

Proceed, Ear.

\section{Song: Sung by Ear}

\section{Tune: 'I've been workin' on the railroad" ${ }^{132}$}

I've been listening to all of you

In this discussion

I've been listening to all of you

And will share my findings.

First, I must confess that

As the Ear I have sinned

I have liked to dis' the dirt on you

Over and over again!

128. Paul mentions that a person who has received the gift of healing (which often is done by the laying on of hands), cannot say to the rest of the body: 'I have no need of you' (see Kistemaker 2002:436).

129.See 1 Titus 2:8

130.See Jeremiah 17:9.

131.Ear, Eye and Head are pretentious and therefore 'inherently humorous', as Trueblood (1964:83-84) observes.

132.The tune to 'I've been workin' on the railroad' is in the public domain; see PD Info (n.d.). 
Please forgive

Please forgive

Me for my sin, my sin, my sin!

I repent

I repent ${ }^{133}$

Over and over again!

[Members of the Body of Christ collectively gasp. Ear hangs his head. A general discussion commences. There is a pause for dialogue, rebuke, repentance, and forgiveness.]

Head:

What did you say about me? I'd like to know.

Foot: You're an eaves dropper! You're a gossip! We should box your ears!

Hand: Or cut them off!

Eye: $\quad$ Libel! I'll slap you with a lawsuit!134

Foot: A gossip separates close friends. ${ }^{135} \mathrm{~A}$ gossip betrays a confidence. ${ }^{136}$

Unpresentable Parts: You have no right talking in an ugly way about us! How dare you! How dare you spread around what I told you as a secret! $!^{137}$

[A general commotion occurs. The members of the Body of Christ are outraged!]

Heart:

Hey, everybody! Hush and listen to me! [Everybody calms down a bit and is eventually quiet.] We have to forgive Ear. Ear has repented and that means Ear won't 'dis' the dirt' on us. ${ }^{138}$ We have to forgive Ear. ${ }^{139}$ If we don't forgive Ear, our heavenly Father won't forgive us our sins. ${ }^{140}$ [Heart looks around.]

Hand:

Right. When the disciples asked Jesus to teach them how to pray, one of the parts of that famous prayer is 'forgive us our sins, for we also forgive everyone who sins against us' ${ }^{141}$

Nose:

Jesus told us to forgive seventy times seven times! ${ }^{142}$

All:

We don't want to. But we have to [Pouting.] Okay. We forgive you, Ear.

133.Ear incorporates a basic principle of worship, namely confession. Confession and pardon fulfil the idea of the reality of sin in personal and communal life (see The Theology and Worship Ministry Unit 1993:35).

134.Lawsuits between and amongst believers in the Corinthian community are an issue (1 Cor 6:1-11; Grams 2011:12). Paul condemns this, saying that 'the very fact that you have lawsuits amongst you means you have been completely defeated already' (1 Cor 6:7a).

135.See Proverbs 16:28.

136.See Proverbs 11:13

137.See Proverbs 20:19.

138.Ear repents, an action showing change. This play, an accompaniment to traditional preaching, may well empower godly change in some lives (see Brueggemann 2005b:25).

139. Whilst Heart recommends forgiveness, Paul asks instead: 'Why not rather be wronged, why not rather be defrauded?' (1 Cor 6:7; see Grams 2011:12).

140.According to Von Balthasar (1992:150), the highest qualification of Jesus who said these words, is that he is the Son of God and the Father's beloved Son.

141. See Luke 11:4.

142.See Matthew 18:22.
Ear:

[Very much relieved.] Thank you, everybody in the Body of Christ. From now on, when I hear something about you, I won't repeat it all over everywhere. I'll discuss it with you privately first. I'll look for the good in each of you and speak well of each of you. I'll pray for you. If you find me in what you think is sin, or if I find you in what I think is sin, let's talk about it privately and see if we can't resolve our issues. $^{143}$

All:

Agreed! That's a good idea. That's what Scripture says.

Ear:

Thank you. Now I'll finish my song. Yes, I am prone to gossip, but I hate that sin so much that, with the Lord Jesus' help, I'll change! I'll tell you what I see in us. [Ear resumes singing.]

\section{Song: Sung by Ear Tune: 'I've been workin' on the railroad'}

Now I'll share what I've seen in us

It is not pretty

Be prepared for a rebuking

That just might bring liberty!

Eye, you're quick to see a scandal!

Head, you're always first!

Hand, I've caught you vandalizing ${ }^{144}$

And Heart, your cheatin' hurts! ${ }^{145}$

Pride is here, you know

Jealousy also

Arrogance and selfishness, I see!

Pride is here, you know

Jealousy also

Arrogance and selfishness.

[Here, all the members of the Body of Christ start shouting and fighting. They are mad at Ear.

Foot:

That was not very nice, Ear! ${ }^{146}$

Heart:

And after we forgave you!

Head:

I don't like to be around you, Ear! Actually, I don't like any of you! I'd rather be out playing golf with unbelievers!

Eye:

Nose, stop picking your nose!

Hand:

Foot, you smell like a locker room! Wash your feet more often!

\section{See Matthew 5:23-24}

144.Bureaucrats, like Head and Hand, 'do not appreciate having their nonresponsiveness exposed to the public eye' (Peter \& Dana 1982:141).

145. Members of the Body of Christ often insult each other. If an insult cannot be ignored, it must be topped; if it cannot be topped, it must be laughed at; if it cannot be laughed at, then probably it is well-deserved (see Peter \& Dana 1982:151).

146. Members of the Body of Christ bicker the same way the disciples jealously disputed who would be the greatest (Lk 22:24-27). Jesus corrected them by introducing the paradox that serving leads to greatness in his new world order (see Trueblood 1964:87-88). 
Heart:

Pull your dress up to your shoulder, Unpresentable Parts! Use the shawl I gave you! ${ }^{147}$

Unpresentable Parts: Nobody tells me what to do!

Nose: Head, you're so arrogant and obnoxious!

Head: I'm gonna punch you in the nose for that, Nose!

[They take up a boxing stand and fisticuffs almost begin.]

$\begin{array}{ll}\text { Eye: } & \text { You're full of pride! } \\ \text { Foot: } & \text { Obnoxious! Rude! } \\ \text { Ear: } & \text { Arrogant! Conceited. } \\ \text { Unpresentable Parts: } & \text { Narcissistic! } \\ \text { Hand: } & \text { Pushy, pushy! } \\ \text { Foot: } & \text { You promote yourself! } \\ \text { Nose: } & \text { You're untruthful. Boorish! } \\ \text { Heart: } & \text { A gossip! You're a big bully! }\end{array}$

[Other insults volley back and forth. Pillows from the sofa also sally through the air.]

Unpresentable Parts: Hand, quit pushing me!

Ear: $\quad$ Foot, you stepped on my toe!

Head: Nose, keep yourself out of my business!

Unpresentable Parts: Hand, stop pinching me!

Eye:

Head, you have too many opinions!

Nose: $\quad$ Foot kicked me!

Foot:

You deserved it!

Head:

How can you judge me when you don't see yourself clearly?

[General confusion and mayhem abounds. Funny Bone separates the various feuding parties and then stands on a chair and starts to shout.]

Funny Bone:

[Funny Bone commands order.] Stop it! ${ }^{148}$ Stop fighting! Stop biting, kicking and shoving! Stop it! ${ }^{149}$ [Everybody stops.]

Funny Bone:

Hand, keep your hands to yourself. Sit over there. Foot, march to that corner! Head, come down out of the clouds. You, Nose, mind your own business and be sure to use a handkerchief! Eye, nobody likes it when you raise your eyebrows. Heart, calm down; remember your blood pressure! Unpresentable Parts, put your shawl around your shoulders. All of you, stop gossiping! All of you, stop thinking ugly thoughts about each other. ${ }^{150}$

147.Corinthian women may have abandoned modest dressing and may even have dressed as men (Loader 2007:82).

148. Funny Bone does not like the qualities she sees the Body of Christ expressing. Characters may or may not appeal to us, and may or may not remind us of ourselves (see DiYanni 2008:922).

149. Here the members of the Body of Christ childishly fight - openly showing their divisions (see 1 Cor 3:1-3). Paul chides his beloved Corinthians 'for failing to allow what they had known and realized to be true to inform their on-going Christian life' (Francis 1980:57).

150.Trueblood (1964:92) observes that some hard problems - whether in exegesis or in life - are 'soluble only in the acids of humor'.
[Chagrined, they obey. They act contrite as they mill around. There even is some general courtesy talk like 'You go first. After you. Please sit here. I'm sorry I yelled at you. I didn't really mean what I said', et cetera.]

Funny Bone:

That's better. Everybody sit down. [Everybody finds a spot. All are touchy and don't want much contact with the others.] Ear, I think you have something more to say.

Ear:

Yes, I do. My song really summed us up. I am included in my own song, for I know I am full of jealousy and pride. We have just shown the whole world our arrogant attitude! [Very sadly.] Oh, what are we to do?

Unpresentable Parts: [Very sadly, too.] Truly, all of us have sinned and fall short of the glory of God. ${ }^{151}$ We're all pretty rotten!

Funny Bone:

Well, yes, we are. But the purpose of seeing our sin is to become free of it. That's why the Lord Jesus came! ${ }^{152}$ That's the gospel! ${ }^{153}$ Jesus seeks to set us free from ourselves, from sin, from the power of Satan and the power of Satan's demons. ${ }^{154}$ [Suddenly taking charge and feeling hopeful.]

Head:

We surely do tear and rend each other. ${ }^{155}$

Heart: [Crying and sincerely sad.] Call me heartbroken!

Nose: $\quad$ [Rubbing his nose.] We're wounded! And bloodied! ${ }^{156}$

Eye: $\quad$ We don't see anything good about each other. ${ }^{157}$

Foot: We get sick and sore. We do not like or honour the parts who we think are weak. ${ }^{158}$

Unpresentable Parts: [Reflectively.] I think we really do like each other - but by the way we act, you'd never know it! ${ }^{159}$ [Hand's hand goes up.]

151.See Romans 3:23.

152.Instead of boasting of our accomplishments, we should boast of 'preferment of one another in love', Francis (1980:57) observes.

153.See Romans 7:24-25.

154.See John 8:36; Luke 13:16; Mark 5:1-20.

155.Anderson $(2006: 100,104)$ correctly sees the Bible as an unfolding story of our lives and God as the great dramatist and storyteller.

156. Rhyne (1990:175-176) writes that 'though the Corinthians may be spiritual, their behavior reflects an unspiritual approach to the faith [...] They are acting like infants rather than grown-ups in Christ'.

157.Themes organise a play (see DiYanni 2008:934). Funny Bone's themes are disunity/unity, each member's importance and the absurdity of 'going it alone' without others.

158. Biblical examples of those who are weak but essential and even invaluable to the body are Dorcas/Tabitha (Ac 9:32-43), the woman who befriended widows in Joppa and was rased from the dead by Peter. She was also the woman who in Joppa and was raised from the dead by Peter. She was also the woman who
anointed Jesus at the home of Simon the leper (Mk 14:1-9), a prophetic act Jesus anointed Jesus

159.Unpresentable Parts believes members of the church are joined together (see Fisk 2000:81) 
Funny Bone:

I agree! But I also must commend you. Thanks to everybody for stopping your fighting - and biting, kicking, shoving, and talking ugly! Hand, would you like to say something?

Hand:

Yes, I would! I believe I can add something positive to our discussion.

\section{Song: Sung by Hand}

\section{Tune: 'Sweet Betsy from Pike'160}

I am the Hand

And I raise it right now

I stand before you

And give you a bow

Let's all work together

And not pull apart

Paul called us yokefellows ${ }^{161}$

We need to start

[Hand dances during the bridge between verses.]

To build God's Kingdom

Is our great call ${ }^{162}$

The right hand of fellowship

Binds us all

His wisdom will guide us

His love is the glue

Through times of sunshine

And days when we're blue.

All:

[Applause.] Well done, Hand!

Eye:

You've got the right idea!

Hand:

Thank you, Body of Christ! Let's listen as Funny Bone teaches us about how we are part of God's Kingdom and how we join with God in building it! ${ }^{163}$

All:

[Excited!] Oh, Funny Bone, please teach us! $!^{164}$

Funny Bone:

With pleasure! Let me remind you what the apostle Paul said in 1 Corinthians 12. ${ }^{165}$ Let's start with the easy section. The body is made up of many parts. And though you are many parts, you form one body. ${ }^{166}$

Nose:

[Laughing and breaking the tension.] Yeah. I like being part of the body. I'll even laugh at your silly jokes about me!

Funny Bone: That's the spirit! That's a good attitude, Nose!

160.The tune to 'Sweet Betsy from Pike' is in the public domain; see PD Info (n.d.)

161.See Philippians 4:3.

162.Jefferson (1924:285) writes that Paul 'possessed the joy of feeling that he was working with God. God has far-reaching plans, and Paul is helping him to carry them out'.

163. Hand recognises Funny Bone's gifts of teaching and friendship. Jefferson (1924:283-284) writes that Paul experienced 'the full joy of friendship' and that (1924:283-284) writes that Paul experie

164.Childers $(1998: 45,49)$, observing that preaching and theatre are events, adds that performance in preaching is a valuable exegetical tool.

165.See 1 Corinthians 12:12-27. Funny Bone, as she begins to teach, follows Stott's (1982:182-187) advice that preaching entails an open-minded, comprehensiv and expectant approach to looking at a text.

166.See 1 Corinthians 12:12.

Head: We all belong to Christ.

All:

Funny Bone:

All:

Funny Bone:

Hand:

All:

[Laughter and high-fives abound.]

Foot:

I'm getting it, I think. I'm remembering Paul's words.

Hand:

We have to be reminded again and again. $^{174}$

Foot:

[Continuing. To Hand.] Yes! If I as the foot say, 'Because I'm not a hand I don't belong to the body', I would not cease to be part of the body. ${ }^{175}$

Hand:

Right! We're stuck with you, Foot! We're stuck with each other, actually. ${ }^{176}$

[Hand and Foot go around with locked arms and in lockstep.]

167 Regarding baptised (1 Cor 12:13) the multi-dimensional and figurative word probably means here Jesus' baptism into death on the cross (1 Cor 10:2; Ac1:5 see Kistemaker 2002:430). Throughout writing the play, I bore in mind the view of Anderson (2006:13) who affirms that, via the Holy Spirit, 'God appears in the cast'.

168.See 1 Corinthians 12:13.

169.Perhaps behind Paul's argument is that male and female together reflect God's image (Gn 1:26-28; Wright 2004:164).

170.Regarding the 1 Corinthians 12 passage, Fisk (2000:79) writes: 'Paul's point is that all such distinctions - of race, class, wealth, gender - must no longer divide those who have been drawn together into the singular, Spirit-empowered body of Christ.' The immersion in the Holy Spirit makes all believers one (Hays 1997:214).

171. Into one body takes into account the unity in diversity of the Body of Christ that's already present in Corinth in terms of racial, cultural, sexual, social and other differences (see Kistemaker 2002:430-431).

172.See 1 Corinthians 12:14.

173. Because of the equality between different parts that have different functions, there is "no room for social, cultural or "spiritual" elitism or snobbery within the church', Wright (2004:164-165) maintains.

174.Brueggemann (2005a:61) writes that the church is either a like-minded group of people who exclude all others, or a group harbouring a generous spirit and a minimum but clear bar of admission.

175.See 1 Corinthians 12:15.

176. Kistemaker (2002:434) comments that a single-unit body 'may be a unit but it is unable to function as an organic body. An entity without any differentiating parts can be as useless as a lump of discarded clay'. 
Ear:

[To Eye.] And if I should say, 'Because I'm not an eye I don't belong to the body', yet as the ear, I could not and would not cease to be part of the body. ${ }^{177}$

Eye: Hey! If the whole body were like me an eye.$^{178}$

Ear:

[Interrupting.] Then how could we hear? And if the whole body were like me - an ear ... ${ }^{179}$

Nose:

[Interrupting and carrying on.] Where then would the sense of smell be? ${ }^{180}$

Head: [Kindly.] Yes, everybody needs a nose. ${ }^{181}$

Nose:

Thank you, Head.

[Nose bows. Laughter and good will suddenly prevail.] $]^{182}$

Heart: That's a good motto!

Funny Bone: $\quad\left[\right.$ Laughing, pleased. ${ }^{183}$ Right! Good insights! We can trust that God has arranged you, parts of the body, just as he wanted you to be! $!^{184}$

Eye:

I get it! There are many parts, but one body. Hand, I need to apologise to you. I certainly said and thought this: 'I don't need you!'185 I was ugly and wrong. I'm sorry. ${ }^{186}$

Head:

[Stiffly, and clearing his throat.] Foot, I likewise owe you an apology, for I commented on your ugly toenails and said I didn't like you or need you! ${ }^{187}$ But hey, you're changing!

Foot:

You're the dude! Hey, I like your haircut!

Funny Bone: [Laughing. $]^{188}$ And Paul goes on. And those parts that are weaker turn out to be indispensable, he says. ${ }^{189}$ And those parts we think of as less honourable, we

177.See 1 Corinthians 12:16.

178.See 1 Corinthians 12:17a.

179.A body that is just one part - be it a nose, ear or eye - is a monstrosity, Fee (1987:611) observes

180.See 1 Corinthians 12:17b

181.Comic breakthrough celebrates with kindness, smiles and understanding, but only 'if we let it expose our mortal vulnerabilities, and are willing, lovingly, to embrace them' (Miller 1995:230).

182.Laughter echoes (Bergson 1924:5)

183.Funny Bone's spontaneity encourages the audience to laugh. Charles (2005:11) comments that 'spontaneous theatre forms ... unmistakably share a common and pervasive audience response: laughter'.

184.See 1 Corinthians 12:18.

185.See 1 Corinthians 12:21a.

186.Eye's apology illustrates that the 1 Corinthians text argues against a member becoming a duplication of another member in order to feel a sense of belonging (see Troupe 2008:40).

187.See 1 Corinthians 12:21b.

188.In my research on laughter, I found these insights from Welsh (1967:97-99) to be up-to-date: we laugh at the unexpected. Slipping on a banana peel is funny when it happens to someone else. Laughter requires a relaxed rather than intense attitude. And laughter serves a social function for it binds together age groups.

189.Paul sees the body in a new way. The Body's more significant, visible members must respect and value those parts considered less so (Fisk 2000:79). are to treat them with more honour. And those parts we call unpresentable, we give even greater honour and make sure to let them have a special modesty. ${ }^{190}$

[All bow. Unpresentable Parts smiles modestly and shows she likes her new shawl. She adjusts it to cover more of her shoulders.]

Unpresentable Parts: I see that God has combined us as members of the Body of Christ and even given special honour, even greater honour to parts that lacked it. ${ }^{191}$

All:

How good and kind is our God!192

Funny Bone:

Yes. That's all true. But, Body of Christ, why is this so? Think about why God does this.

[They all walk around talking aloud. The following are quickly spoken.]

Eye: $\quad$ Because he wanted to. ${ }^{193}$

Foot: Because he's good.

Nose: $\quad$ Because he's just.

Heart: Because he loves us all equally!

Ear: $\quad$ Because it's his plan for the church.

Hand: Because Jesus commanded us to love one another.

Head: $\quad$ Funny Bone wants one reason. Let's get in a huddle, and let's remember what Paul wrote.

[They get in a huddle. Funny Bone smiles and gives them space.]

[Murmurs from the huddle include the following comments that are quickly given.]

Hand:

I can't remember.

Nose: $\quad$ I wasn't very good in school about memorising.

Foot: Isn't it something about unity?

Unpresentable Parts: Hey, I thought it was division.

Eye: That's it. I've got it! I remember! It's so that there's no division! ${ }^{194}$ We're not supposed to be divided!195

[As the members break out of the huddle, they are very pleased.]

Eye:

Let's say it together.

All:

So that there's 'no division' in the body! ${ }^{196}$

190.See 1 Corinthians 12:22-23. The weaker body parts present a surprise: they are indispensable (Fisk 2000:80)!

191.See 1 Corinthians 12:24.

192.The kindness of God leads to repentance (Rm 2:4; Tt 3:4; Eph 2:7).

193. Robinson (2001:243) provides a good rule for writing a sermon or play: let supporting material restate, repeat and explain a pericope's parts.

194.The Greek word perichoresis describes the happy fellowship of the Father, Son and Spirit. Arends (2008) likens the word to being worn out with gladness.

195.The passage emphasises unity. Anderson (2006:81) writes that the biblical text, in contrast to Greek dramas that think of history in terms of cycles, moves toward an end in which God's purpose will be realised (see 1 Cor 15:24-28).

196.See 1 Corinthians 12:25a; 3:1-9. One division was 'parties' - some claimed to belong to Paul or Cephas or Apollos or Christ (1 Cor 3:4-5; see Rhyne 1990:174). 
Funny Bone:

[Laughing joyfully.] Right! Paul writes that there should be no division within the Body of Christ. The goal is equal concern of one for the other. ${ }^{197}$

Foot:

Well, since our last meeting I sprained my ankle badly and was on crutches for two weeks.

Hand: $\quad$ And I cut my finger almost to the bone.

Head: $\quad$ My head aches all the time. ${ }^{198}$

Eye: $\quad$ I have eyestrain from studying too much.

[Unpresentable Parts, Heart, and Nose show concern in all this.]

Unpresentable Parts: [Sighing.] If one of you suffers, I suffer. ${ }^{199}$ Nose: $\quad$ So do I! Paul said that and I agree! $!^{200}$

[They cry together; Heart brings a tissue.]

Funny Bone: $\quad$ Yes, if one suffers, all suffer. (Brightly.) But if one is honoured, all are honoured, too! ${ }^{201}$ We all rejoice! ${ }^{202} \mathrm{Mmm}$. Let me teach you from Scripture. ${ }^{203}$

\section{Rap: Chanted by Funny Bone (All and Head break in)}

[Rap rhythm can be like this: Beat, Beat, Shhhhhhhhhhhhhh. Or like this:

Beat, Beat, Beat, Beat, Beat Beat Shhhhhhhhh. Or like this:

Beat, Beat, Beat, Beat. This is probably the easiest rhythm. It allows for rests. For example, 'Seek to do good' is in three beats plus a rest; 'Just as God' has two beats and two beats of rest. The downbeat for the 4/4 beat is on the first word in each line of the rap.

Funny Bone can walk in time, snap fingers, take the whole stage, dance, et cetera.]

Head: Let's give her a beat.

[Four 'snappers' come forward. They can be, for example, Hand, Eye, Nose, and Head. They form a 'back up' group like 'doo-ah' singers following a lead crooner. A simple snapping beat is one, two, three, four.]

Funny Bone:

Great! I'll give you the tempo! [She sets the beat she finds comfortable. This beat continues throughout her rap.]

\section{See 1 Corinthians $12: 25 b$}

198. Ramelli (2011:146) notes that 'disease and death can be understood in a spiritual sense' and indeed are understood in this way 'by most ancient exegetes'.

199.See 1 Corinthians 12:26a. Kistemaker (2002:438) says this passage 'describes the effect genuine care can have on members in the Christian church'.

200.Paul stresses that the Corinthians must behave rightly toward each other to recover spiritual health and life, and to avoid judgment (Ramelli 2011:163).

201.Bailey (2011:347) observes that Paul reminds his beloved congregation that members of the Body of Christ are clothed in splendour and honour. They are also bound to one another in life's ups and downs of suffering and honour.

202.See 1 Corinthians 12:26b.

203.Funny Bone begins teaching in a contemporary way: rap. Drama is a tool enabling both young and old to remember biblical teachings and act on them (McNabb \& Mabry 1990:21).

204.Whilst writing the rap, I bore in mind Childers' (1998:80) view that the foundation of a careful, skilled oral performance (whether for preaching, teaching or acting) contains four elements: rate, pitch, volume and pause. Proper emphasis transforms a dead reading or a dead performance into an enlivened event (see Childers ibid:84).
Funny Bone (Rapping to the beat.):

Jesus said it this way ${ }^{205}$

Jesus said it this way

Love one another ${ }^{206}$

Love one another

As I have loved you

As I have loved you ${ }^{207}$

Paul added this.

All:

Paul added this.

Funny Bone:

By love, by love,

By love serve one another. ${ }^{208}$

All:

By love, by love,

By love serve one another. ${ }^{209}$

Funny Bone:

Seek to do good

Seek to do good

Especially to those

Especially to those.

All:

In the Body of Christ

In the Body of Christ. ${ }^{210}$

Funny Bone:

Proverbs, James, and Peter

Proverbs, James, and Peter

All say this:

All say this

Love covers

Love covers ${ }^{211}$

All:

Well, Funny Bone

Well, Funny Bone

What does love cover?

What does love cover?

Funny Bone:

A multitude of sins!

A multitude of sins!

Love covers

Love covers

A multitude of sins!

A multitude of sins!

Head:

Sum it up, Funny Bone

Sum it up, Funny Bone.

205.McNabb and Mabry (1990:25-26) give guidelines about interpreting any passage by finding its main point, considering the context, lookimg at the whole book and reading the individual part in light of the book and scripture as a whole. They also consider how the passage applies to life today. Funny Bone gives audience also consider how the passage applies to life today. Funny Bone gives audience
members a non-threatening and humorous way to see strengths and weaknesses

206.Dever (2011:97) writes that we are indeed 'obliged to love one another'.

207.See John 15:12.

208. How is this love meant to be expressed? By active sympathy among the members, and by members going out of their way to care for others and seeking to carry others' burdens (Dever 2011:98).

209.See Galatians 5:13.

210.See Galatians 6:10. Tone, language, and repetition, a playwright's tools and present in literary analysis, overlap throughout the play (see Lostracco \& present in literary

211.See Proverbs 10:12; James 5:20; 1 Peter 4:8 


\section{Funny Bone:}

Be kind, one to another

Compassionate

Forgiving each other

Just as God

Just as God

Just as God in Christ

Just as God in Christ

Has forgiven you

Has forgiven you.

\section{All:}

Bee bop, ooooeeeoo!

Bee bop, ooooeeeoo!

Ephesians four, thirty-two

Ephesians four, thirty-two! ${ }^{12}$

[General applause, laughter. ${ }^{213}$ Funny Bone bows.]

Head:

Hear, hear! This is all well and good. But Funny Bone, it is now time to consider your request. Body of Christ, this is important! Body of Christ, to the huddle! $!^{124}$

[Head starts singing and directing. The characters gradually assemble toward the centre rug. ${ }^{215}$ They huddle. ${ }^{216}$ Funny Bone goes to the side respectfully.]

\section{Song: Sung by Head Tune: 'Yankee Doodle Dandy'17}

This song starts with the tune from 'Yankee Doodle Dandy' that starts with this line: 'Father and I went down to camp.' [When told by Head, Funny Bone goes upstage on cue with a bow. She prays:]

Hurry up now, Body of Christ

Get into formation

Funny Bone, excuse yourself $\mathrm{f}^{218}$

And so avoid confusion

Let us all be orderly

Let us all be civil

Let us all debate and see

Meeeeeeee moderate decisively!

212. In a performance, $I$ encourage my actors to stress the fun of this rap and the joy of being forgiven. The Pilgrim Hymnal (1966:194) contains a Percy Dearmer hymn The whole bright world rejoices now'. Notice its emphasis on hilarity:

'The whole bright world rejoices now, Hilariter, Hilariter; The birds do sing on every bough, Alleluia, Alleluia.

Then shout beneath the racing skies, Hilariter, Hilariter. To him who rose that we might rise, Alleluia (2x).

And all you living things make praise, Hilariter, Hilariter; He guideth you on all your ways, Alleluia, Alleluia!

$\mathrm{He}$, Father, Son, and Holy Ghost, Hilariter, Hilariter; Our God most high, our joy and boast, Alleluia, Alleluia!

213.Laughter, as Funny Bone shows, is individual and social, physiological and psychological as well as caused and causative (Welsh 1967:96).

214.Again, Head takes charge, but Troupe (2008:44) asks: 'Who decides who should be the head?'

215.A prop like a rug helps 'the where' of a scene (see Lostracco \& Wilkerson 2008:31)

216.I incorporated the idea of a huddle from church polity. This huddle is a congregational meeting. Although enacted with humour, it nonetheless conveys the sense of discussing the issue that is before the Body of Christ. Making Corinthians 12 a musical comedy has several advantages including the followin (cf. Clark, Brubaker \& Zuck 1986:545-546):

- Enacting a story makes it more real and gives the actor, via imagination, insights into another person.

- A drama may show honest feelings.

217.The tune to 'Yankee Doodle Dandy' is in the public domain; see PD Info (n.d.).

218. Funny Bone involves entrances and exits, characters and plot, scenes and settings, tone and dialogue, pauses and monologues (see Vanhoozer 2005:41).
[The members shake their heads at Head's pomposity, but follow his directions.]

Head: Should Funny Bone be recognised?

Ear:

Eye:

Heart:

Unpresentable Parts: Because of what she said, I am not jealous of you all anymore, and I am not ashamed of who I am. Even I am needed in the Body of Christ.

Nose:

She helped us remember Paul's words. We had forgotten them!

Hand: But admitting Funny Bone has to be based on Scripture, not just because we like her.

Head: Or that she makes us laugh. ${ }^{221}$

Nose:

Jesus certainly had a sense of humour. ${ }^{222}$ So did Paul. ${ }^{223}$

All:

You're right about that!224

Heart:

Well, the reason we're in the Body of Christ is that we're mentioned in Proverbs and Psalms or elsewhere in the Bible.

Foot:

Right. There are lots of verses in which I figure prominently. Consider Psalm 1:1: 'Blessed is the man who does not walk in the counsel of the wicked.' Here's a verse about protection. Psalm 121:3: 'He will not let your foot slip.'

Hand:

I like this one about me. Psalm 47:1: 'Clap your hands, all you nations! Shout to God with cries of joy!'

219.'The church can afford to take the risk of the humorous and ephemeral, because the joke is God's and the laughter is divine,' Wells (2004:69) writes. Laughter keeps Funny Bone involved with people (Swindoll 1991:225).

220. Eye and Heart appreciate Funny Bone's ability to fuss at them with a twinkle in her eye. Trueblood sees the same in Jesus. He (Trueblood 1964:15) writes: 'Anyone who reads the Synoptic Gospels with a relative freedom from presuppositions might be expected to see that Christ laughed, and that He expected others to laugh, but our capacity to miss this aspect of His life is phenomenal.'

221. Here are some meanings of humour present in Funny Bone (Arbuckle 2008:2): - Humour, or the comic, helps us cope with the vicissitudes of life.

- Humour is negative when it degrades a person. Humour is positive when it respects a person's dignity.

- Positive humour evokes two types of laughter. The first response is audible you can hear a laugh. The second is an interior laughter - a laughter of the heart, if you will, which manifests itself in joy and peace.

222.Trueblood (1964:47) calls Jesus' humour 'deliberately preposterous'; that phrase applies to portions of Funny Bone that exaggerate to make a point

223.Jefferson (1924:280-282) links Paul's character and joy:

In the outer courts of his soul there is often pain and sometimes agony, but in the inner court there is always the sound of music and dancing. Underneath the surface of his letters there runs a strain of deep and solemn gladness. Again the again it is hidden from the eye and ear, but it keeps the joy of hope. Hope always wears a radiant face.

224.Jesus was gregarious and so often in fellowship with so-called questionable characters that he was termed 'a wine-bibber and gluttonous man' (Welsh 1967:103). 
Heart:

Head:

Eye:

Unpresentable Parts: A whole book is written about me, or at least it seems to be! The Song of Songs is red hot and ready! Listen to parts of chapter 4 . [She recites or reads. A Bible on a lectern may be part of the stage props.]

'How beautiful you are, my darling! Oh, how beautiful! Your eyes behind your veil are doves. Your hair is like a flock of goats descending from Mount Gilead. Your teeth are like a flock of sheep just shorn, coming up from the washing. Each has its twin; not one of them is alone. Your lips are like a scarlet ribbon; your mouth is lovely. Your temples behind your veil are like the halves of a pomegranate. Your neck is like the tower of David, built with elegance; on it hang a thousand shields, all of them shields of warriors. Your two breasts are like two fawns, like twin fawns of a gazelle that browse amongst the lilies ... All beautiful you are, my darling: there is no flaw in you. ${ }^{225}$

All: $\quad$ [Applause.]That was lovely, Unpresentable Parts.

[Unpresentable Parts bows.] ]226

Ear:

Here's a good verse about me. Isaiah 30:21: 'Whether you turn to the right or to the left, your ears will hear a voice behind you saying, "This is the way, walk in it."'

Nose:

Scripture often describes sacrifices as sweet savours to the Lord. Here's a description from Genesis 8: 'Then Noah built an altar to the Lord and, taking some of all the clean animals and clean birds, he sacrificed burnt offerings on it. The Lord smelled the pleasing aroma.'

Head: But are there Bible verses about Funny Bone or things Funny Bone does?

Hand: How about this: laughter is the best medicine.

Head:

That's a good start. But it's practical wisdom. It is not in the Bible.

225.See Song of Songs 4:1-7. Brueggemann (2005b:25) challenges preachers (and playwrights) to see a text in a new way that is 'credible and evocative of a new playwrights) to see a text in a new way that is 'credible and ev
humanness, rooted in holiness and practiced in neighborliness'.

226. DiYanni (2008:921) writes that a playwright arranges incidents. For example, each character's song allows for smiles and a relaxation of intensity, but the church fight of shoving and poking may cause some uncomfortable feelings in the audience.
Heart:

I've got it, Body of Christ! I've got a verse about Funny Bone, about what Funny Bone does! [Heart whispers the scripture in the huddle.]

Nose:

That's good! Let's all say it.

[They turn from the huddle. Funny Bone looks up from prayer and stands waiting.]

Eye: Heart, you've hit a home run!

Head:

[Shouting.] Funny Bone, we've decided. Come back in!

[Funny Bone enters.]

Heart:

Funny Bone, on behalf of the Body of Christ, we value you and invite you to fully participate in the Body of Christ as a named member. You belong. You're needed. ${ }^{227}$ Here's the scripture verse to prove it:

All:

'A merry heart doeth good like a medicine.' Proverbs 17:22. ${ }^{228}$

[General goodwill prevails. The sincerity is in marked contrast to the forced, strained good will at the entrance.]

Ear:

Here's another scripture: Isaiah 61:3 says that the Lord gives 'a crown of beauty instead of ashes, the oil of gladness instead of mourning, and a garment of praise instead of a spirit of despair'.

Foot:

And Jesus told his disciples many things on the night he was betrayed. Why did he do this? John 15 recounts Jesus' words: 'I have told you this so that my joy maybe in you and that your joy may be complete.'

Funny Bone:

Thank you, Body of Christ! I am thrilled to be part of you! My favourite scripture about me is this from Nehemiah 8: 'The joy of the Lord is your strength!' [Good will prevails. $]^{229}$

Unpresentable Parts: Well, another song is required, don't you think? $?^{230}$
Ear:
[Smiling.] Most certainly. ${ }^{231}$

[Everybody groups downstage centre stage and starts singing. They pause and bow as their names are mentioned. Funny Bone sings the first entry of 'And Funny Bone is with us now too'. All sing the last two lines.]

227. McNabb \& Mabry (1990:164) categorise teaching as promoting creativity or engaging in ordinariness. Funny Bone falls in their creative category.

228.Cousins (1979:83) gives his own version of this verse: 'a merry heart works like a doctor.'

229. Funny Bone was written for enjoyment and teaching purposes. A spectator's pleasure in watching a play 'remains a reference to that delight that underlies and sustains all life's seriousness, a delight in being privileged to share in existence', writes Von Balthasar (1988:267).

230.Studies show people retain $10 \%$ of what they read and hear, but that 'direct purposeful experiences', like acting, produce a $90 \%$ retention rate (McNabb \& purposeful experip
Mabry 1990:42).

231.Duckworh (1999:5) correctly writes that a 'skit can brighten a worship service with humor and, at the same time, drive home a serious point'. 


\section{Song: Sung by All ${ }^{232}$ Tune: 'Of the Father's love begotten'233}

Of Christ's Body now in unity We will function in harmony For we love and honour Jesus As our life and liberty

Of Christ's Body we are Hand, Foot, Head, Ear, Heart, Eye Nose and Unpresentable Parts

And Funny Bone is with us now, too

And Funny Bone is with us now, too

And Funny Bone is with us now, too. ${ }^{234}$

\section{Conclusion}

Funny Bone ends with unity within the believing community. Bonhoeffer (1954:21) writes that 'Christianity means community through Jesus Christ and in Jesus Christ.' Bonhoeffer (ibid:21) explains that an individual Christian 'needs others because of Jesus Christ'. Funny Bone's cast of 10 certainly learns this. They speak God's word to each other and return to their foundation: the centrality of Christ in their lives. The play began by showing a misplaced pride and lack of community commitment. These traits produced disunity, or what Bonhoeffer (ibid:23) aptly calls 'discord between God and man and between man and man'. Bonhoeffer (ibid:24) rightly says that the cast's unity can continue 'only by way of Jesus Christ. Only in Jesus Christ are we one, only through him are we bound together.'

Funny Bone ends happily - as musicals do. Yet, as a realist and cradle Presbyterian, I realise that unity is temporary even when iced with humour, dance and song. Bumps in the road - 'hiccups' as life's trials are humorously called in South Africa - are normal. However, when things go awry, this musical provides a template for public confession and forgiveness, and a model for communal discussion of problems.

\section{Acknowledgements}

The author thanks Pam Walker, librarian at Victory University in Memphis, Tennessee, for her help in verifying that all Funny Bone's tunes are in the public domain. The author thanks Dr George Fluitt and Dr Clarice Fluitt, pastors of the Eagle's Nest Church in Monroe, Louisiana, for their encouragement of song, dance, creativity and member participation during worship services and other church activities in the 1980s. My idea for Funny Bone started because of church skits that used laughter to teach biblical principles.

232.This song stressing unity provides what Robinson (2001:244) calls a strong conclusion. Everybody in the play is transformed in some way; everybody grows. Brueggemann (2005b:20) notes that a congregation's transformation does not occur through didacticism, but through 'the playful entertainment of anothe scripting of reality that may subvert the old given text and its interpretation and lead to the embrace of an alternative text and its redescription of reality'.

233.The tune to 'Of the Father's love begotten' is in the public domain (Pilgrim Hymnal 1966:111); see PD Info (n.d.).

234.Osmer bemoans the lack of educated 'thoughtful' preaching today. Research on pastors, he (Osmer 2008:81) writes, gives 'depressing findings of ... how little they read once they have graduated from seminary'. Funny Bone bucks this trend, for it is thoroughly researched, as its bibliography and footnotes show.

\section{Competing interests}

The author declares that she has no financial or personal relationship(s) that may have inappropriately influenced her in writing this article.

\section{References}

Allard, R.E., 2010, '"Freedom on your head" (1 Corinthians 11:2-16): A paradigm for the structure of Paul's ethics', Word \& World 30(4), 399-407.

Anderson, B.W., 2006, The unfolding drama of the Bible, Fortress Press, Minneapolis.

Arbuckle, G.A., 2008, Laughing with God: Humor, culture, and transformation, Liturgical Press, Collegeville.

Arends, C., 2008, 'Carbonated holiness: Laughter is serious business', Christianity Today, March, 74.

Bailey, K.E., 2011, Paul through Mediterranean eyes: Cultural studies in 1 Corinthians, InterVarsity Press, Downers Grove.

Bergson, H., 1924, Laughter: An essay on the meaning of the comic, transl. C. Brereton \& F. Rothwell, Macmillan Company, New York.

Berryman, J.W., 1999, 'Laughter, power, and motivation in religious education', Religious Education 93(3), 358-378. http://dx.doi.org/10.1080/0034408980930308

Bolte, C. \& McCusker, P., 1993, Short skits for youth ministry, Group Publishing, Loveland.

Branch, R.G., 2004, 'Life's choices: A play based on eight characters in Proverbs', Christian Higher Education: A Journal of Applied Research and Practice 4(1), 57-69.

Branch, R.G., 2010a, Jeroboam's wife: The enduring contributions of the Old Testament's least-known women, Baker Academic Publishers, Grand Rapids.

Branch, R.G., 2010b, 'He is risen! A play based on Acts 1:1-12', In die Skriflig 44(1), 229-258. http://dx.doi.org/10.4102/ids.v44i1.145

Branch, R.G., 2013a, 'When Mary tells Joseph: A play based on Matthew 1:18-19', In die Skriflig 47(1).

Branch, R.G., 2013b, 'Astonishment and joy: Luke 1 as told from the perspective of Elizabeth', In die Skriflig 47(1).

Bonhoeffer, D., 1954, Life together, transl. J.W. Doberstein, Harper \& Row Publishers, New York.

Brown, D., 2008, God and mystery in words: Experience through metaphor and drama, University Press, Oxford. http://dx.doi.org/10.1093/acprof:0 so/9780199231836.001.0001

Brueggemann, W., 2005a, 'An imaginative "Or"', in D. Day, J. Astley \& L.J. Francis (eds.), A reader on preaching: Making connections, pp. 51-64, Ashgate Publishing, Burlington.

Brueggemann, W., 2005b, 'Preaching as reimagination', in D. Day, J. Astley \& L.J. Francis (eds.), A reader on preaching: Making connections, pp. 17-29, Ashgate Publishing, Burlington.

Charles, D., 2005, 'The power of the carnival satirist: Taking laughter seriously', Journal of Theater and Performance 2(2), 11-28.

Childers, J., 1998, Performing the word: Preaching as theatre, Abingdon Press, Nashville.

Clark, R.E., Brubaker, J. \& Zuck, R.B. (eds.), 1986, Childhood education in the church, Moody, Chicago.

Cloninger, C., 1999, Drama for worship: Contemporary sketches for opening hearts to God, vol.2, Standard Publishing, Cincinnati.

Copenhaver, M.B., 2007, 'Laughter at Easter: Matthew 28:1-10', Journal for Preachers 30(3), 15-18.

Cousins, N., 1979, Anatomy of an illness as perceived by the patient: Reflections on healing and regeneration, Bantam Books, New York.

Dever, M., 2011, 'The Church: A summary and reflection', in A.J. Kostenberger \& R.W. Yarbrough (eds.), Understanding the times: New Testament studies in the 21st century, pp. 87-103, Crossway, Wheaton.

DiYanni, R., 2008, Literature: Approaches to fiction, poetry, and drama, McGraw-Hill, Boston.

Duckworth, J., 1999, High-impact worship dramas: Quick-prep message boosters for pastors \& church leaders, Group, Loveland.

Edyvean, A.R., 1970, This dramatic world: Using contemporary drama in the church, Friendship Press, New York.

Fee, G.D., 1987, The first epistle to the Corinthians, Eerdmans, Grand Rapids.

Eslinger, R.L., 2005, 'Story and image in sermon illustration', in D. Day, J. Astley \& L.J. Francis (eds.), A reader on preaching: Makingconnections, pp. 175-178, Ashgate Publishing, Burlington.

Fisk, B.N., 2000, First Corinthians, Geneva Press, Louisville.

Francis, J., 1980, "'As babes in Christ" - Some proposals regarding 1 Corinthians 3:1-3', Journal for the Study of the New Testament 7(1), 41-60. http://dx.doi. org/10.1177/0142064X8000200703

Glavich, M.K., 2002, Catholic school kids say the funniest things, Paulist Press, New York. 
Grams, R.G., 2011, 'The shaping of Christian convictions and the avoidance of ideology: Paul's contribution to a vexing issue in 1 Corinthians', Baptistic Theologies 3(1) 1-14.

Hays, R.B., 1997, First Corinthians, John Knox Press, Louisville.

Hill, A.E. \& Walton, J.H., 2000, A survey of the Old Testament, Zondervan, Grand Rapids. Iverson, K.R., 2011, 'The redemptive function of laughter: Performance and the use of humor in the Gospel of Mark', paper presented at the annual meeting of the Society of Biblical Literature, San Francisco, 19-22 November.

Jefferson, C.E., 1924, The character of Paul, Macmillan, New York.

Robert McEwen Esq, 2009, 'Is the song "Home on the Range" in the public domain?" in Just Answer. ${ }^{\otimes}$ Intellectual Property Law, viewed 17 May 2013, from http:// www.justanswer.com/intellectual-property-law/2pdiq-song-home-range-publicdomain

Kistemaker, S.J., 2002, 1 Corinthians, Baker Books, Grand Rapids. PMid:11858818

Loader, W., 2007, The New Testament with imagination: A fresh approach to its writings and themes, Eerdmans, Grand Rapids.

Long, T.G., 2001, Beyond the worship wars: Building vital and faithful worship, Alban Institute, N.P.

Lostracco, J. \& Wilkerson, G., 2008, Analyzing short stories, Kendall/Hunt Publishing Company, Dubuque.

McNabb, B. \& Mabry, S., 1990, Teaching the Bible creatively: How to awaken your kids to scripture, Zondervan, Grand Rapids.

Miller, J.A., 1995, 'Laughter and the absurd economy of celebration', Cross Currents 45(2), 217-233.

Murfin, R. \& Ray, S.M., 1997, The Bedford glossary of critical and literary terms, Bedford Books, Boston.

Osmer, R.R., 2008, Practical theology: An introduction, Eerdmans, Grand Rapids.

Peter, L.J. \& Dana, B., 1982, The laughter prescription: How to achieve health, happiness, and peace of mind through humor, Ballantine Books, New York.

Pilgrim Hymnal, 1966, The Pilgrim Press, Boston.

Pitzele, P.A., 1998, Scripture windows: Towards a practice of bibliodrama, ALEF Design Group, Los Angeles.

Public Domain Information Project (PD Info) n.d., List of public domain music, viewed from http://www.pdinfo.com/Public-Domain-Music-List.php

Quash, B., 2005, Theology and the drama of history, Cambridge University Press, Cambridge. http://dx.doi.org/10.1017/CBO9780511487811, PMid:15985231 Ramelli, I.L.E., 2011, 'Spiritual weakness, illness, and death in 1 Corinthians 11:30',
Journal of Biblical Literature 130(1), 145-163.

Rhyne, C.T., 1990, ' 1 Corinthians 3:1-9', Expository Articles: Interpretation 44(2), 174179. http://dx.doi.org/10.1177/002096438904400207
Rice, W. \& Yaconelli, M., 1987, The greatest skits on earth: Skits with a message, Zondervan, Grand Rapids.

Robinson, H.W., 2001, Biblical preaching: The development and delivery of expository messages, Baker Academic, Grand Rapids.

Smalley, S.S., 1968, 'Spiritual gifts and 1 Corinthians 12-16', Journal of Biblical Literature 87(4), 427-433. http://dx.doi.org/10.2307/3263304

Steuernagel, V.R., 2003, 'Doing theology with an eye on Mary', Evangelical Review of Theology 27(2), 100-112.

Stevenson-Moessner, J., 2008, Prelude to practical theology: Variations on theory and practice, Abingdon, Nashville.

Stonehouse, C., 1998, Joining children on the spiritual journey: Nurturing a life of faith, Baker Books, Grand Rapids.

Stott, J., 1982, Between two worlds: The challenge of preaching today, Eerdmans, Grand Rapids.

Swindoll, C.R., 1991, Laugh again, Word Publishing, Dallas. PMid:1786452

The book of common worship, 1946, Office of the General Assembly, United Presbyterian Church in the United States of America, Philadelphia.

The service for the Lord's Day, 1984, The worship of God: Supplemental liturgical resource 1, The Westminster Press, Philadelphia.

Urdang, J. \& Urdang, L., 1973, The Random House dictionary of the English language, J. Stein (ed.), Random House, New York.

The Theology and Worship Ministry Unit, 1993, Book of common worship, Westminster/John Knox Press, Louisville.

Troupe, C., 2008, 'One body, many parts: A reading of 1 Corinthians 12:12-27', Black Theology: An International Journal 6(1), 32-45. http://dx.doi.org/10.1558/ blth2008v6i1.32

Trueblood, E., 1964, The humor of Christ, Harper \& Row, New York.

Vanhoozer, K.J., 2005, The drama of doctrine: A canonical linguistic approach to Christian theology, Westminster John Knox Press, Louisville.

Von Balthasar, H.U., 1988, Theo-drama: Theological dramatic theory, vol. 1, transl. G. Harrison., Ignatius Press, San Francisco. (I: Prolegomena).

Von Balthasar, H.U., 1992, Theo-drama: Theological dramatic theory, vol. 3, transl. G. Harrison, Ignatius Press, San Francisco. (III: The dramatis personae - The person in Christ).

Wells, S., 2004, Improvisation: The drama of Christian ethics, Brazos Press, Grand Rapids.

Welsh, W.A., 1967, 'Homo Ridens: A preliminary consideration of some aspects of human laughter', Lexington Theological Quarterly 2(4), 95-103.

Wright, T., 2004, Paul for everyone: 1 Corinthians, SPCK/WJK Press, Louisville. 